\title{
Efeito da temperatura e do fotoperíodo na germinação in vitro de conídios de Cercospora beticola, agente etiológico da cercosporiose da beterraba
}

\author{
Leandro Luiz Marcuzzo ${ }^{1}$, Aline Nascimento ${ }^{1}$
}

\begin{abstract}
${ }^{1}$ Instituto Federal Catarinense - IFC/Campus Rio do Sul, CP 441, 89.163-356, Rio do Sul, SC
Autor para correspondência: Leandro Luiz Marcuzzo (marcuzzo@ifc-riodosul.edu.br)

Data de chegada: 11/02/2016. Aceito para publicação em: 11/04/2016.
\end{abstract}

A produção nacional de beterraba é uma das mais significativas dentro do mercado agrícola de hortaliças (Filgueira, Novo manual de olericultura: agrotecnologia moderna na produção e comercialização de hortaliças. 3.Ed. Viçosa:UFV, 2007, 421p.). Na região do Alto Vale do Itajaí/SC, o cultivo da beterraba é normalmente praticado na primavera/verão por pequenos produtores após a cultura da cebola, o que faz com que a atividade tenha uma grande importância socioeconômica, tanto pela sua intensiva utilização de mão de obra, como pela boa rentabilidade, responsável pela sustentabilidade de pequenas propriedades agrícolas. Porém a principal doença que incide sobre esta cultura é a cercosporiose da beterraba causada por Cercospora beticola (Weiland \& Koch. Sugar beet leaf spot disease (Cercospora beticola Sacc.). Molecular Plant Pathology, v.5, p.157$166,2004)$. Os sintomas característicos iniciais são pontuações que evoluem e tendem a alcançar de 4 a $5 \mathrm{~mm}$, de formato mais ou menos arredondado, centro claro e bordas de coloração vermelho-púrpura. À medida que as lesões aumentam, se tornam com tonalidade acinzentada, porém, com a necrose, o tecido lesionado cai e a folha torna-se perfurada. $\mathrm{O}$ aumento do número de lesões e o crescimento da área induzem à senescência e à redução significativa da área foliar (Marcuzzo et al. Cultivar HF, n.1, p.14-15, 2014). A planta repõe as folhas a partir de reservas da raiz, o que pode causar a redução de rendimento e da produtividade (Puiatti \& Finger, Cultura da beterraba. In: Fontes. Olericultura: teoria e prática. Viçosa: Suprema, p.345-354, 2005). Sabe-se que a germinação de esporos de fungos é influenciada diretamente pela temperatura e fotoperíodo, no entanto as informações desse patógeno são escassas. O conhecimento da biologia do patógeno é de importância para compreender o desenvolvimento da doença no campo, bem como para tomar medidas de manejo da doença. Diante disto, este trabalho teve como objetivo avaliar in vitro a influência da temperatura e do fotoperíodo na germinação de conídios de $C$. beticola. A pesquisa foi realizada no Laboratório de Microbiologia e Fitopatologia do Instituto Federal Catarinense/Campus Rio do Sul com isolado identificado de $C$. beticola, obtido de plantas de beterraba com sintoma da doença através de isolamento monospórico. O experimento foi em delineamento inteiramente casualizado com cinco repetições. $\mathrm{O}$ isolado foi multiplicado em placas de Petri contendo o meio de cultura extrato de tomate ( $200 \mathrm{~g}$ de extrato de tomate, $3,0 \mathrm{~g} \mathrm{de} \mathrm{CaCO}_{3}$, $20 \mathrm{~g}$ de ágar e $1000 \mathrm{ml}$ de água destilada), utilizando-se a técnica de repicagem por esfregaço (Marcuzzo et al. Summa Phytopathologica, v.41, n.1, p.74, 2015). Posteriormente as placas foram incubadas em câmaras de germinação do tipo Biological Oxigen Demand (B.O.D) a $25^{\circ} \mathrm{C}$ e fotoperíodo de 12 horas durante o período de sete dias. Após isso os conídios foram removidos através de raspagem com pincel e água esterilizada e espalhou-se com auxílio de alça de Drigalski $100 \mu 1$ de suspensão de conídios contendo a concentração de $1,0 \times 10^{5}$ conídios/mL em placas de Petri com meio ágar-água 1\%. Em seguida, as placas foram incubadas a temperaturas de 10, 15, 20, 25, 30 e $35^{\circ} \mathrm{C}$ em escuro contínuo. Em um segundo momento repetiu-se o experimento incubando conídios de C. beticola a $25^{\circ} \mathrm{C}$ (temperatura ideal de germinação obtida com o experimento da temperatura) com os fotoperíodos de 0, 6, 12, 18 e 24 horas de luz. Em ambos os experimentos foi avaliada a percentagem de germinação após 24 horas de incubação. Para visualização dos conídios foi adicionado algumas gotas de azul de metileno $0,33 \%$ e com movimentos circulares espalhou-se as gotas a fim de cobrir toda a superfície com o corante. A contagem foi feita com microscópio óptico com magnitude de 100 vezes através da contagem de 100 conídios aleatórios na placa. Foi considerado germinado o que tivesse o tubo germinativo maior que o tamanho do conídio. Com base nos dados obtidos, constatou-se que a temperatura exerce grande influência sobre a germinação dos conídios de C. beticola. Observase que entre as temperaturas de 25 e $30^{\circ} \mathrm{C}$ (Figura 1A) houve a maior percentagem de germinação variando ente 67 e $82 \%$ respectivamente. Isso reflete o que acontece no campo, pois a temperatura ideal para o desenvolvimento da cercosporiose varia entre 22 e $26^{\circ} \mathrm{C}$ (Tivelli et al. Beterraba, do plantio a comercialização. Série Tecnologia APTA. Boletim Técnico IAC, 210. Campinas: Instituto Agronômico. p.45, 2011; Hermann, Reconnaître les maladies foliaires de la betterave au champ. Institut Royal Belgepourl'Amérlioration de la Betterave (IRBAB/KBIVB), 1998. Disponível em: <http://www.irbab-kbivb. be/.../GuideMaladiesFoliaires.pdf $>$. Acesso em: 28 mai 2015). Pelos dados obtidos observa-se que na temperatura de $35^{\circ} \mathrm{C}$ a percentagem de germinação foi de $15 \%$, sendo $63 \%$ inferior a germinação a $30^{\circ} \mathrm{C}$. Isso também foi constatado por Racca \& Jörg (CERCBET 3 - a forecaster for epidemic development of Cercospora beticola. Bulletin OEPP/ EPPO Bulletin, v.37, p.344-349, 2007) quando avaliaram o efeito da temperatura na esporulação constataram decréscimo quando a temperatura passou de 30 para $35^{\circ} \mathrm{C}$. A germinação dos conídios também foi bruscamente reduzida nas temperaturas de 10 e $15^{\circ} \mathrm{C}$ sendo de $15 \%$ e $21 \%$ respectivamente. A maior germinação ocorreu quando se elevou a temperatura de 20 para $25^{\circ} \mathrm{C}$, com $38 \%$ de acréscimo. Mediante a isso, C. beticola tem sua germinação favorecida em temperaturas médias de $25^{\circ} \mathrm{C}$ e isto acontece durante a primavera/verão na região do Alto Vale do Itajaí/SC durante o ciclo da beterraba, favorecendo a germinação dos conídios e consequentemente a ocorrência da doença. Na Figura 1B observa-se a influência do fotoperíodo na germinação de conídios de C. beticola, onde ocorre um efeito inibitório sobre a germinação. Nos fotoperíodos de $0,6,12$, 18 e 24 horas, obteve-se respectivamente 83,2; 74,$2 ; 67 ; 66,2$ e 53,8\% de germinação. Ressaltando que o fotoperíodo exerce pouca influência na germinação de conídios, diferindo-se apenas $29,4 \%$ do maior para o menor percentual de geminação. Conclui-se que a germinação dos conídios de $C$. beticola sofre pouca influência do fotoperíodo e alto efeito da temperatura, onde as maiores percentagens de germinação foram obtidas em temperaturas de 25 a $30^{\circ} \mathrm{C}$, sendo 
A

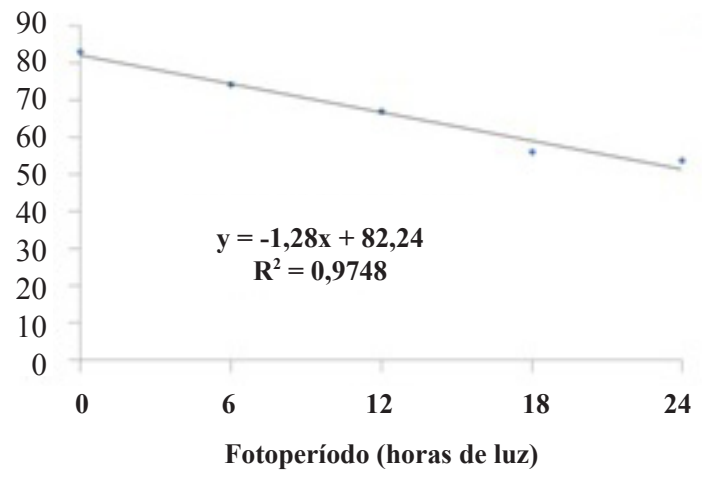

Figura 1. Curva de germinação de conídios de Cercospora beticola sob diferentes temperaturas (A) e fotoperíodos (B). IFC/Campus Rio do Sul, 2015.

a ótima $25^{\circ} \mathrm{C}$. As informações obtidas em relação à temperatura e o fotoperíodo na germinação dos conídios de C. beticola permitem um maior conhecimento da biologia do agente causal da cercosporiose da beterraba, auxiliando assim no entendimento da epidemiologia da doença no campo. Os resultados obtidos servirão de suporte na elaboração de um sistema de previsão da doença. 